\title{
EVALUASI PELAKSANAAN PROGRAM IMUNISASI DASAR DI PUSKESMAS LUBUK BUAYA TAHUN 2017
}

\author{
Afrizal $^{1}$, Edison $^{2}$, Firdawati $^{3}$ \\ Prodi Sarhana Keperawatan, STIKes MERCUBAKTIJAYA Padang, Jalan Jamal Jamil \\ Pondok Kopi Siteba Padang \\ email: av.afrizal@yahoo.com
}

Submitted : 26-06-2020, Reviewer:27-06-2020, Accepted: 30-06-2020

\begin{abstract}
Abstrak
Program imunisasi merupakan salah satu program untuk melindungi penduduk secara spesifik terhadap Penyakit yang Dapat Dicegah Dengan Imunisasi (PD3I). Kejadian Luar Biasa (KLB) Difteri pada tahun 2015 pada wilayah kerja Puskesmas Lubuk Buaya paling tinggi (37,5\%). Adanya kesenjangan ini menjadi dasar untuk melakukan evaluasi pelaksanaan program imunisasi dasar. Penelitian ini adalah penelitian kualitatif untuk melakukan evaluasi dari pelaksanaan program imunisasi dasar, dengan metoda wawancara mendalam, FGD, telaah dokumen dan observasi. Pada hasil penelitian diketahui bahwa ketenagaan untuk pelaksanaan imunisasi sudah memadai namun tenaga pelaksana imunisasi belum pernah mengikuti pelatihan khusus imunisasi, dana untuk pelaksanaan program sudah memadai, sarana dan prasarana sudah mencukupi, SOP pelaksanaan imunisasi sudah tersedia. Perencanaan imunisasi berdasarkan acuan dari dinas kesehatan, pelayanan imunisasi dilakukan di dalam dan di luar gedung, masih ada petugas imunisasi yang belum melaksanakan SOP. Pencatatan dan pelaporan dimulai dari pembina wilayah ke puskesmas kemudian dilanjutkan ke dinas kesehatan. Supervisi dan bimbingan teknis sudah terlaksana dari dinas ke puskesmas, pimpinan puskesmas hanya supervisi secara berkala ke klinik/BPS belum terlaksana supervisi ke posyandu saat pelaksanaan imunisasi. Cakupan imunisasi masih belum mencapai target karena faktor pemahaman masyarakat, dan faktor teknis pelaksanaan program. Dari hasil penelitian masih perlu dilaksanakan pelatihan khusus imunisasi bagi tenaga pelaksana imunisasi di lapangan. Diperlukan koordinasi lintas sektoral yang maksimal dengan pemerintahan kecamatan dan kelurahan.
\end{abstract}

Kata kunci: Evaluasi, Program Imunisasi Dasar, Puskesmas

\begin{abstract}
The immunization program is one program specifically to protect the population against diseases certain, that is some Preventable Diseases Immunization (PD3I). Extraordinary Events (KLB) Diphtheria in 2015 in Lubuk Buaya Community Health Center is highest (37.5\%). The existence of this gap is the basis for evaluating the implementation of the basic immunization program. This study is a qualitative study to conduct an evaluation of the implementation of the basic immunization program, with the method of indepth interviews, focus group discussions, review of documents and observation. In the research result shows that the workforce for the implementation of the immunization is adequate but immunization executive power has never participated in a special training immunization, funding for the implementation of the program is adequate, facilities and infrastructure are sufficient, SOP implementation immunizations are available. Planning immunization is based on the reference of health services, immunization services performed inside and outside the building, there is still immunization workers who have not implemented the SOP. Recording and reporting starting from the builder to the clinic area and then proceed to the health department. Supervision and technical guidance has been implemented from offices to hospitals, health centers led only periodic supervision to the clinic/BPS has not been done to the Community Health Center supervision during the implementation of immunization. Immunization coverage has yet to reach the target because of the people's understanding and technical factors of the program.From the results of research still needs to be implemented special training immunizations for executive personnel in the field of
\end{abstract}


immunization. Necessary maximum inter-sectoral coordination with district and village governments in support of the implementation of the immunization program.

Keywords: Evaluation, Imunization Basics, Community Health Center

\section{PENDAHULUAN}

Era MDGs tahun 2000-2015 Indonesia ternyata belum dapat mencapai target menurunkan Angka Kematian Bayi dan Balita, periode selanjutnya untuk mencapai Visi Indonesia Sehat dalam penyempurnaan MDGs Indonesia yang merupakan salah satu negara telah ikut menyepakati Tujuan Pembangunan Berkelanjutan (Sustainable Development Goals) dengan lebih 190 negara di dunia. Pada tujuan SDGs yang ketiga Indonesia menargetkan pada tahun 2030 berusaha menurunkan Angka Kematian Neonatal setidaknya hingga 12 per 1.000 kelahiran hidup dan Angka Kematian Balita 25 per 1.000 kelahiran hidup (Kemenkes, 2015).

Kementerian Kesehatan menargetkan pada tahun 2014 seluruh desa/kelurahan mencapai 100\% UCI (Universal Child Immunization) atau 90\% dari seluruh bayi di desa/kelurahan tersebut memperoleh imunisasi dasar lengkap yang terdiri dari BCG, Hepatitis B, DPT-HB, Polio dan campak. Pencapaian UCI desa/ kelurahan tahun 2014 baru mencapai 82,9\% yang perlu ditingkatkan hingga mencapai 92\%. Hal ini disebabkan antara lain karena kurang perhatian dan dukungan dari pemerintah daerah terhadap program imunisasi, kurangnya dana operasional untuk imunisasi baik rutin maupun tambahan, dan tidak tersedianya fasilitas dan infrastruktur yang adekuat. Selain itu juga kurangnya koordinasi lintas sektor termasuk pelayanan kesehatan swasta, kurang sumber daya yang memadai serta kurangnya pengetahuan masyarakat tentang program dan manfaat imunisasi (Kemenkes, 2015).

Salah satu imunisasi dasar yang yang menjadi target pencapaian UCI adalah imunisasi DPT-HB. Imunisasi DPT-HB sebanyak 3 (tiga) kali untuk memberi kekebalan pada penyakit difteri, pertusis (batuk rejan), tetanus dan Hepatitis B. Imunisasi ini pertama kali diberikan pada usia bayi 2 (dua) bulan. Kemudian imunisasi berikutnya selisihnya 4 minggu. Pada saat ini pemberian imunisasi DPT dan Hepatitis B dalam program imunisasi dilakukan bersamaan dengan menggunakan vaksin DPT-HB (Kemenkes, 2010).

Kejadian Luar Biasa (KLB) penyakit difteri yang sudah ditetapkan oleh Wali Kota Padang berdasarkan tempat tinggal pasien tersebar dari beberapa Kecamatan di Kota Padang, yaitu Kecamatan Padang Timur 1 kasus, Kecamatan Kuranji 1 kasus, Kecamatan Padang Barat 1 kasus, Kecamatan Padang Utara 1 kasus, dan Kecamatan Koto Tangah sebanyak 3 kasus. Kejadian luar biasa yang terjadi di Kota Padang ini merupakan indikator bahwa program imunisasi tidak mencapai sasaran (Dinkes Sumbar, 2015).

Berdasarkan data cakupan Kelurahan Universal Child Immunization (UCI) pada tahun 2014 kota Padang baru mencapai angka $76 \%$ sudah lebih tinggi dari capaian UCI Propinsi Sumatera Barat yaitu 74,87\% dan berada di bawah capaian UCI Indonesia $82,3 \%$. Sedangkan data cakupan imunisasi DPT-HB pada kota Padang 87,12\% dimana juga lebih tinggi dari capaian cakupan Propinsi Sumatera Barat $84,1 \%$ dan masih berada dibawah capaian cakupan data imunisasi DPT-HB Indonesia 95\% (Dinkes Padang, 2015).

Kasus Difteri yang terjadi di kota Padang berdasarkan laporan Bidang Pengendalian Masalah Kesehatan Dinas Kesehatan Kota Padang pada tahun 2014 
yaitu sebanyak 8 kasus yang tersebar di Kota Padang, dan kasus yang paling banyak yaitu 37,5\% terjadi di Kecamatan Koto Tangah pada wilayah kerja Puskesmas Lubuk Buaya. Data pencapaian UCI menurut puskesmas Kota Padang Puskesmas Lubuk Buaya sudah mencapai target yaitu $100 \%$, sedangkan data pencapaian cakupan iminisasi DPT-HB di Puskesmas Lubuk Buaya sudah dalam kategori tinggi yaitu 94,7\% (Dinkes Padang, 2015).

Pencapaian target UCI dan tingginya cakupan imunisasi DPT-HB ternyata tidak menjamin tercapainya tujuan akhir program imunisasi dalam menurunkan angka kesakitan dan kematian yang disebabkan oleh penyakit menular yang dapat dicegah dengan imunisasi. Banyak faktor yang dapat mempengaruhi keberhasilan program imunisasi yaitu berkaitan dengan status imun penjamu, faktor genetik penjamu, dan faktor dari vaksin itu sendiri yang berhubungan dengan penyimpanan, pemberian dosis, pengenceran vaksin (IDAI, 2015). Faktor yang tidak bisa diabaikan dalam pencapaian tujuan suatu program adalah berkaitan dengan mutu/kualitas pelaksanaan program tersebut. Penilaian pelaksanaan suatu program apakah sudah berjalan dengan baik sesuai dengan perencanaan dan standar yang sudah ditetapkan dapat dilakukan suatu kegiatan evaluasi (Azwar, 2010).

Evaluasi adalah suatu kegiatan yang dilakukan untuk memberikan penilaian terhadap program yang sudah berjalan ataupun yang sedang berjalan. Untuk kepentingan praktis, ruang lingkup evaluasi (penilaian) tersebut dibedakan menjadi empat kelompok yaitu 1) evaluasi terhadap masukan (input), 2) evaluasi terhadap proses (process), 3) evaluasi terhadap keluaran (output), dan 4) evaluasi terhadap dampak (impact) (Azwar, 2010).

\section{METODE PENELITIAN}

Penelitian ini adalah penelitian kualitatif yaitu untuk melakukan evaluasi dari pelaksanaan program imunisasi dasar di Puskesmas Lubuk Buaya Kecamatan Koto Tangah Kota Padang. Penelitian kualitatif ini di gunakan untuk menggali informasi mengenai pelaksanaan imunisasi dasar.

Penelitian ini dilaksanakan di Puskesmas Lubuk Buaya Kecamatan Koto Tangah Kota Padang, pengumpulan data dilaksanakan pada bulan Oktober 2017.

Informan pada penelitian ini sebanyak 14 (empat belas) orang untuk indepth interview dan 8 (delapan) orang ibuibu yang memiliki anak usia 1-3 tahun untuk FGD (Fokus Group Discussion).

\section{HASIL DAN PEMBAHASAN}

Hasil penelitian ini akan membahas masukan (input), proses (process) dan keluaran (ouput) sesuai dengan tujuan penelitian yang sudah ditetapkan. Masukan meliputi tenaga, dana, sarana dan prasarana serta pedoman teknis dan SOP pada pelaksanaan imunisasi dasar. Proses terdiri dari perencanaan, pelaksanaan, pencatatan dan pelaporan serta supervisi dalam pelaksanaan imunisasi dasar. Sedangkan keluaran untuk mengetahui capaian cakupan imunisasi dasar yang sudah dilakukan di wilayah kerja Puskesmas Lubuk Buaya Kota Padang.

Tenaga pengelola imunisasi ada pada setiap tingkat mulai tingkat propinsi sampai pada tingkat puskesmas. Tenaga pelaksana di tingkat puskesmas terdiri dari petugas imunisasi, pelaksana cold chain dan pengelola program imunisasi. Tenaga pelaksana di tingkat kabupaten/kota terdiri dari pengelola program imunisasi, pengelola vaksin dan cold chain. Dari hasil wawancara mendalam terhadap informan didapatkan data bahwa tenaga pelaksana program imunisasi sudah cukup dari segi jumlah dan sesuai kualifikasi pendidikannya namun belum adanya pelatihan khusus imunisasi bagi tenaga pelaksana di lapangan. Perlu 
adanya pembenahan keterampilan petugas untuk peningkatan pencapaian program.

Hasil observasi pada saat pelayanan imunisasi, ditemukan petugas tidak memberikan penyuluhan sebelum pemberian imunisasi secara maksimal yang berhubungan dengan jenis vaksin, manfaat imunisasi, akibat apabila tidak diberi imunisasi, kemungkinan terjadinya KIPI dan upaya-upaya yang harus dilakukan.

Berdasarkan hasil penelitian diketahui bahwa tenaga untuk pelaksanaan program imunisasi yang ada di Puskesmas Lubuk Buaya sudah cukup dari segi jumlah dan sesuai kualifikasi pendidikannya baik pengelola program yang ada di puskesmas maupun pelaksana yang ada di lapangan atau posyandu dengan berpendidikan minimal DIII Kebidanan dan D-III Keperawatan. Namun masih belum ada pelatihan imunisasi khusus bagi pelaksana imunisasi di lapangan, mereka hanya diberikan informasi pelatihan pada saat lokakarya mini (lokmin) di puskesmas oleh pimpinan. Petugas-petugas yang sudah mengikuti pelatihan selama ini tapi tidak mempunyai sertifikat. Pada puskesmas tidak ada tenaga khusus pengelola logistik imunisasi tapi ketenagaannya dirangkap oleh penanggung jawab program imunisasi di puskesmas.

Penelitian tentang faktor yang berhubungan dengan cakupan imunisasi dipengaruhi oleh keberadaan tenaga pelaksana. Pelakasanaan program imunisasi mutlak memerlukan ketersediaan tenaga pelaksana imunisasi karena ini akan mempengaruhi lingkungan dan perilaku masyarakat untuk melaksanakan imunisasi (Afriyanti, 2009). Penelitian tentang Pengaruh Pendidikan dan Pelatihan terhadap Sikap dan Keterampilan Petugas Pengelola Vaksin Program Imunisasi pada Unit Pelayanan Kesehatan di Kabupaten Cirebon, menunjukkan bahwa terdapat perbedaan yang bermakna sikap dan keterampilan petugas sebelum mengikuti pelatihan dengan sesudah pelatihan pengelolaan vaksin program imunisasi (Sasongko, 2011).

Penelitian tentang Evaluasi Program Imunisasi Puskesmas di Kota Makasar tahun 2012 menyatakan ada permasalahaan terhadap tenaga pelaksana di tingkat puskesmas dimana terdapat $52,6 \%$ petugas yang memiliki tugas rangkap di puskesmas. Pelaksanaan program imunisasi harus didukung oleh tenaga teknis yang memiliki kapasitas dan kompetensi dalam memberikan pelayanan khususnya pelayanan lapangan dan pengelola logistik (Kemenkes, 2013).

Pelatihan merupakan salah satu upaya peningkatan pengetahuan, sikap dan keterampilan petugas/pengelola imunisasi dalam rangka meningkatkan kinerja dan kualitas petugas. Pelatihan yang dilaksanakan tersebut diharapkan terakreditasi dan mempunyai sertifikat. Pelatihan dapat diselanggarakan secara berjenjang oleh kementerian, pemerintah provinsi, pemerintah kabupaten/kota dan atau lembaga swasta yang telah terakreditasi oleh kementerian (Kemenkes, 2017).

Tenaga pada pelaksanaan program imunisasi akan merencanakan dan akan menghasilkan pelayanan terhadap masyarakat sebagai penerima pelayanan imunisasi, tenaga pelaksana yang tidak memiliki keahlian atau kompetensi yang tidak memadai maka mustahil tujuan pelayanan dalam melaksanakan program imunisasi akan tercapai dengan maksimal. Perlu dilaksanakan pelatihan untuk peningkatan kapasitas petugas/pelaksana program imunisasi dalam rangka mewujudkan pelayanan imunisasi yang berkualitas.

Berdasarkan hasil pengumpulan data penelitian sumber dana untuk pelaksanaan program imunisasi adalah yang berasal dari Pusat dan dari dana BOK untuk operasional pelaksanaan program imunisasi. Sumber pendanaan untuk imunisasi dapat berasal dari pemerintah dan sumber pembiayaan lain 
yang sah sesuai dengan peraturan perundangundangan. Pendanaan yang bersumber dari pemerintah berbeda-beda pada tiap tingkat administrasi, tingkat pusat bersumber dari Anggaran Pendapatan Belanja Negara (APBN), tingkat propinsi bersumber dari APBN (dekon) dan Anggaran Pendapatan Belanja Daerah (APBD) propinsi, tingkat kabupaten/kota bersumber dari APBN (tugas perbantuan) dan APBD kabupaten/kota berupa DAU (Dana Alokasi Umum) dan DAK (Dana Alokasi Khusus).

Fungsi pemerintah pusat adalah dalam menjamin ketersedian vaksin dan alat suntik serta safety box, bimbingan teknis, pedoman pengembangan, pemantauan dan evaluasi, pengendalian kualitas, kegiatan TOT (Training of trainer), advokasi, penelitian operasional, dan KIE (Komunikasi Informasi dan Edukasi). Pemerintah daerah kabupaten/kota bertanggung jawab menyiapkan biaya operasional untuk pelaksanaan pelayanan imunisasi, Biaya operasional yang dimaksud adalah transport dan akomodasi petugas, bahan habis pakai, penggerakan masyarakat, perbaikan serta pemeliharaan peralatan rantai vaksin dan kendaraan imunisasi, distribusi logistik dari kabupaten/kota sampai ke fasilitas pelayanan kesehatan, dan pemusnahan limbah medis imunisasi. Anggaran pembiayaan penyelenggaraan imunisasi yang ada ini secara berkesinambungan tentu akan berkaitan dengan ketercapaian tujuan pelaksanaan program imunisasi ke depannya. (Kemenkes, 2017).

Hasil penelitian tentang kelengkapan sarana dan prasarana untuk pelaksanaan program imunisasi di Puskesmas Lubuk Buaya sudah tersedia dengan lengkap dari ketersedian vaksin dan peralatan cold chain.

Hasil penelitian tentang Faktor yang Berhubungan dangan Cakupan Imunisasi di Kabupaten Tegal menunjukkan bahwa puskesmas yang ketersediaan sarana prasarana vaksinnya memadai berhubungan dengan cakupan imunisasi, sedangkan puskesmas yang tidak memadai sarana prasarana vaksinnya mempunyai resiko memiliki cakupan imunisasinya dalam kategori rendah (Afriyanti, 2009).

Pemerintah bertanggung jawab terhadap penyediaan logistik imunisasi program yaitu penyediaan vaksin, ADS, safety box dan peralatan cold chain berupa alat penyimpanan vaksin yang meliputi cold room, freezer room, vaccine refrigerator, dan freezer, alat transportasi vaksin meliputi kendaraan berpendingin khusus, cold box, vaccine carrier, cool pack, dan cold pack, dan alat pemantau suhu, meliputi termometer, termograf, alat pemantau suhu beku secara terus menerus dan alarm (Kemenkes, 2017).

Sarana dan prasarana yang dibutuhkan dalam pelaksanaan program imunisasi merupakan logistik imunisasi, peralatan cold chain dan alat transportasi vaksin. Kelengkapan persediaan sarana dan prasarana dalam memberikan pelayanan imunisasi akan sangat membantu proses pelayanan lebih cepat dan akan meningkatkan kelancaran serta kenyamanan dalam memberikan pelayanan kepada masyarakat (Kemenkes, 2013).

Hasil penelitian menunjukkan bahwa petunjuk teknis yang digunakan dalam pelaksanaan imunisasi di Puskesmas Lubuk Buaya dengan menggunakan SOP untuk melakukan pelayanan imunisasi. Pedoman penyelenggaraan imunisasi akan memberikan acuan tentang jenis imunisasi, penyelenggaraan imunisasi program, penyelenggaraan imunisasi pilihan, pemantauan dan penanggulangan KIPI, penelitian dan pengembangan, peran serta masyarakat, pencatatan dan pelaporan, serta pembinaan dan pengawasan (Kemenkes, 2017).

Standar Operasional Prosedur (SOP) merupakan urutan langkah-langkah suatu pekerjaan, ini diperlukan dalam pelaksanaan 
tugas untuk mencapai tujuan dari hasil suatu pekerjaan. SOP sebagai suatu acuan memuat tentang prosedur dari suatu rangkaian kegiatan secara efektif dan efisien berdasarkan standar dan ketentuan yang sudah ada. Dalam pelaksanaan program imunisasi SOP ini harus menjadi pedoman dalam memberikan pelayanan imunisasi agar pemberian pelayanan sesuai dengan standar yang sudah ditetapkan.

Berdasarkan hasil penelitian proses perencanaan program imunisasi di Puskesmas Lubuk Buaya dibuat setiap awal tahun dengan berpedoman kepada perencanaan secara umum yang dibuat oleh Dinas Kesehatan Kota Padang, kemudian baru di buat perencanaan sasaran imunisasi per kelurahan yang ada di wilayah kerja puskesmas. Penelitian Peran Petugas dangan Cakupan Imunisasi Tingkat Puskesmas di Kabupaten Jember menunjukkan bahwa ada hubungan aspek perencanaan yang dibuat dengan cakupan imunisasi (Zakiyah, 2013). Perencanaan harus disusun secara berjenjang, mulai dari puskesmas, kabupaten/kota, propinsi dan pusat (bottom up). Perencanaan merupakan kegiatan yang sangat penting sehingga harus dilakukan secara benar oleh petugas yang profesional. Ketidaktepatan dalam perencanaan akan mengakibatkan terhambatnya pelaksanaan program, tidak tercapainya target kegiatan, pemborosan keuangan negara, serta hilangnya kepercayaan masyarakat. Perencanaan untuk pelaksanaan program imunisasi meliputi penentuan sasaran, perencanaan kebutuhan logistik yang meliputi perencanaan vaksin, perencanaan Auto Disable Syringe, perencanaan safety box, perencanaan kebutuhan peralatan cold chain dan terakhir perencanaan pendanaan (Kemenkes, 2013).

Berdasarkan hasil pengumpulan data terhadap pelaksanaan program imunisasi di Puskesmas Lubuk Buaya bahwa pelayanan imunisasi diberikan secara rutin di puskesmas dan di posyandu sesuai jadwal.
Sesuai dengan hasil FGD dengan ibu-ibu yang mempunyai anak usia 1-3 tahun menyimpulkan bahwa pelaksanaan imunisasi selama ini sudah berlangsung dengan baik karena sudah sesuai dengan jadwal dan petugasnya selalu ada.

Masih ada permasalahan dari petugas imunisasi yang berhubungan dengan sikap petugas dalam memberikan edukasi dan komunikasi saat memberikan pelayanan imunisasi. Hasil FGD menyimpulkan ada petugas yang menyampaikan sesuatu dengan gaya komunikasinya secara terang-terangan kadang-kadang membuat masyarakat tersinggung seperti menyampaikan anak mereka kurang gizi, sehingga mereka enggan untuk datang pada kegiatan posyandu berikutnya.

Hasil observasi ditemukan petugas tidak memberikan penyuluhan sebelum pemberian imunisasi secara maksimal, dimana petugas tidak menginformasikan secara jelas yang berhubungan dengan jenis vaksin, manfaat imunisasi, akibat apabila tidak diberi imunisasi, kemungkinan terjadinya KIPI dan upaya-upaya yang harus dilakukan.

Hasil penelitian menemukan bahwa gaya petugas kesehatan di posyandu menghasilkan persepsi yang negatif bagi masyarakat. Tenaga kesehatan seharusnya tidak bersikap menggurui, tetapi berbicara pada tingkat yang sama dan dapat mengkomunikasikan penghargaan dan menghormati perbedaan pandangan (Hutagaol, 2012). Komunikasi petugas dengan masyarakat sebenarnya bertujuan supaya antara petugas dengan mayarakat yang dilayani dapat saling bertukar pikiran dalam membantu menyelesaikan masalah yang dihadapi dan mendengarkan adalah cara yang baik untuk dapat menerima pesan secara benar dan lengkap.

Pemeliharaan cold chain secara umum sudah terlaksana sesuai ketentuan namun masih ada ketidakdisiplinan petugas dalam 
melakukan pencatatan pengontrolan suhu kulkas vaksin setiap hari. Berdasarkan observasi pada pelaksanaan pelayanan imunisasi di temukan masih ada petugas yang melakukan tindakan pelayanan yang tidak sesuai dengan SOP, dan tidak melakukan pengelolaan limbah dengan menggunakan safety box.

Berdasarkan hasil observasi pada Bidan Praktek Swasta/klinik yang melaksanakan pelayanan imunisasi dasar ditemukan bahwa pemeliharaan cold chain tidak dilakukan sesuai standar, dimana ditemukan penyimpanan vaksin pada kulkas pendingin minuman/kulkas rumah tangga dan vaksin disimpan dengan barang-barang yang lain, serta tidak ada termometer untuk mengontrol suhu lemari pendingin.

Penelitian Faktor-faktor yang Berhubungan dengan Kepatuhan Petugas terhadap SOP Imunisasi menunjukkan bahwa sebanyak $39,1 \%$ petugas dikategorikan tidak patuh dalam melaksanakan SOP imunisasi, variabel independen yang paling dominan berhubungan dengan kepatuhan petugas adalah pengetahuan dan sarana prasarana (Yulianti, 2010).

Ketidak patuhan petugas terhadap SOP pada pelaksanaan pelayanan imunisasi, pengelolaan rantai dingin dan pengelolaan limbah tentu akan berpengaruh kepada kualitas vaksin. Hasil penelitian FaktorFaktor Resiko Kualitas Pengelolaan Vaksin Program Imunisasi yang Buruk di Unit Pelayanan Swasta Studi Kasus di Kota Semarang. Hasil penelitian menunjukkan bahwa, petugas dengan pengetahuan yang kurang baik mempunyai risiko 31,6 kali menyebabkan kualitas pengelolaan vaksin menjadi buruk dibandingkan dengan nilai pengetahuan yang baik. Kesalahan membawa vaksin berisiko 9,4 kali lebih besar menyebabkan kualitas pengelolaan vaksin menjadi buruk dibandingkan dengan vaksin yang dibawa dengan benar (Kristini T, 2008). Sejalan dengan penelitian Hubungan
Pengetahuan dan Sikap Pengelola Vaksin dengan Skor Pengelolaan Vaksin di Daerah Kasus Difteri di Jawa Timur menemukan bahwa pelatihan petugas dalam mengelola vaksin berpengaruh terhadap ketepatan dalam pengelolaan vaksin di tempat pelayanan kesehatan (Pracoyo, 2013).

Untuk menjaga kualitas vaksin tetap tinggi sejak diterima sampai didistribusikan pada tingkat berikutnya vaksin harus selalu disimpan pada suhu yang telah ditetapkan yaitu pada puskesmas semua vaksin disimpan pada suhu $2^{\circ} \mathrm{C}-8^{\circ} \mathrm{C}$ pada vaccine refrigerator. Penyimpanan pelarut vaksin pada suhu $2^{\circ} \mathrm{C}-8^{\circ} \mathrm{C}$ atau pada suhu ruang terhindar dari sinar matahari langsung. Sehari sebelum digunakan pelarut disimpan pada suhu $2^{\circ} \mathrm{C}-8^{\circ} \mathrm{C}$. Untuk mempertahankan kualitas vaksin tetap tinggi perlu dilakukan pemeliharaan sarana peralatan cold chain dengan melakukan pengecekan suhu dengan menggunakan thermometer atau alat pemantau suhu digital setiap pagi dan sore, termasuk hari libur, memeriksa apakah terjadi bunga es dan memeriksa ketebalan bunga es apabila bunga es lebih $0,5 \mathrm{~cm}$ lakukan defrosting (pencairan bunga es), memeriksa apakah terdapat cairan pada dasar lemari es apabila terdapat cairan harus segera dibersihkan atau dibuang, melakukan pencatatan langsung setelah pengecekan suhu pada thermometer atau pemantau suhu dikartu pencatatan suhu setiap pagi dan sore (Depkes, 2009).

Berdasarkan hasil pengumpulan data dari pencatatan dan pelaporan pelaksanaan imunisasi di Puskesmas Lubuk Buaya dapat diketahui bahwa proses pencatatan dan pelaporan sudah berjalan sebagaimana mestinya, namun masih ada penyampaian laporan dari jejaring puskesmas yang tidak tepat waktu setiap bulannya. Pencatatan dan pelaporan pelaksanaan program imunisasi disampaikan setiap bulan, pelaporan dimulai dari hasil pelaksanaan imunisasi di posyandu-posyandu yang ada di lingkungan 
pembina wilayah masing-masing. Pembina wilayah melakukan perekapan hasil pelaksanaan imunisasi di wilayah binaannya yang bersumber dari pelayanan di posyandu digabung dengan pemberian iminisasi yang dilaksanakan oleh jejaring puskesmas seperti Bidan Praktek Swasta (BPS) dan klinikklinik yang memberikan pelayanan imunisasi, dan kemudian ditambahkan dengan pemberian imunisasi di puskesmas terhadap sasaran yang berdomisili di daerah binaan yang bersangkutan.

Hasil pencatatan imunisasi dilakukan oleh setiap unit yang melakukan kegiatan imunisasi, mulai dari puskesmas pembantu, puskesmas, rumah sakit umum, Kantor Kesehatan Pelabuhan, balai imunisasi swasta, rumah sakit swasta, dan klinik swasta kemudian disampaikan kepada pengelola imunisasi kabupaten/kota (Kemenkes, 2013).

Berdasarkan hasil pengumpulan data tentang supervisi dalam pelaksanaan program imunisasi di Puskesmas Lubuk Buaya diperoleh bahwa supervisi sudah terlaksana dari dinas maupun oleh puskesmas dan sekaligus sudah ada bimbingan teknis dari dinas dan puskesmas terhadap pelaksanaan imunisasi. Belum terlaksananya supevisi lintas sektor secara rutin dari kelurahan dan kecamatan. Berdasarkan informasi yang didapatkan tidak berjalannya supervisi dari lintas sektor secara rutinitas disampaikan ada hubungannya dengan sumber daya manusia yang terbatas.

Hasil penelitian Evaluasi Pelaksanaan Fungsi Manajemen Kegiatan Program Imunisasi Bayi di Puskesmas Kabupaten Bangkalan Madura. Hasil penelitian menunjukkan bahwa Supervisi pelaksanaan kegiatan imunisasi telah berjalan. Monitoring sudah dilaksanakan meskipun ada satu puskesmas non UCI tidak melakukan monitoring. Pelaksanaan monitoring di Puskesmas ini hanya dilakukan oleh Dinas Kesehatan saja (Ifadhotul A, 2009). Sebagai salah satu fungsi manajemen adalah melaksanakan supervisi yaitu melakukakan pengamatan yang dilakukan secara langsung dan berkala oleh atasan terhadap pekerjaan yang dilakukan oleh bawahan dan kemudian apabila ditemukan masalah segera diberikan petunjuk atau bantuan yang bersifat langsung untuk mengatasi masalah yang ada (Azwar, 2010).

Supervisi yang dilakukan oleh puskesmas khususnya ke unit-unit pelayanan swasta yang berada di wilayah kerja puskesmas perlu ditingkatkan kualitasnya terutama untuk melakukan pembinaan tentang pengelolaan vaksin dengan benar bagi petugas/pelaksana imunisasi. Kecamatan dan kelurahan untuk dapat mengidentifikasi masalah-masalah yang terjadi pada pelaksanaan imunisasi di masyarakat sebaiknya melakukan kunjungan atau peninjauan langsung pada saat pelayanan imunisasi.

Berdasarkan pengumpulan data penelitian tentang cakupan imunisasi dasar di Puskemas Lubuk Buaya didapatkan bahwa untuk saat ini cakupan imunisasi belum mencapai target yang ditetapkan, yang disebabkan oleh berbagai faktor dimulai dari dasar penetapan sasaran imunisasi yang tidak sesuai dengan realita di lapangan karena letak wilayah kerja Puskesmas Lubuk Buaya yang berada di zona merah, kemudian adanya isuisu negatif yang sampai ke masyarakat tentang vaksin untuk imunisasi, kemudian adanya pemahaman dan pola pikir masyarakat yang masih rendah tentang imunisasi.

Upaya pencapaian target cakupan imunisasi masih memerlukan evaluasi yang menyeluruh dari pelaksanaan program imunisasi selama ini. Evaluasi terhadap pelaksanaan oleh petugas mulai dari perencanaan, pemberian pelayanan, sampai kepada pencatatan dan pelaporan pelaksanaan imunisasi itu sendiri. Dari perencanaan diperlukan pendataan yang akurat terhadap sasaran pada setiap wilayah, 
pelaksanaan masih perlu evaluasi dari tenaga pelaksana dalam memberikan edukasi dan komunikasi kepada masyarakat serta masih perlu dilakukan pelatihan-pelatihan kepada petugas yang belum pernah mengikuti pelatihan imunisasi selama ini.

Koordinasi lintas sektoral menjadi perhatian untuk kedepannya karena untuk terlaksananya program imunisasi secara efektif dan efisien maka perlu adanya koordinasi lintas sektor terutama dengan kecamatan dan kelurahan karena dengan keikutsertaan lintas sektor ini bisa nantinya secara bersama- sama untuk mengidentifikasi masalah-masalah yang ada dalam pelaksanaan imunisasi ini di masyarakat, dan mencari jalan keluarnya untuk dapat menggerakkan dan memotivasi masyarakat untuk bisa mengikuti program imunisasi.

$$
\text { Dalam mendukung untuk }
$$
terlaksananya program imunisasi diperlukan advokasi dan pendekatan-pendekatan kepada pihak yang memiliki pengaruh di masyarakat yaitu tokoh masyarakat dan tokoh agama agar dapat meluruskan ideologi tentang vaksin kearah yang benar dan memberikan bantahan terhadap ideologi yang salah tentang vaksin oleh masyarakat. Dengan melibatkan tokoh-tokoh masyarakat dan tokoh agama diharapkan terjadinya peningkatan dan kepercayaan imunnisasi di tengah masyarakat secara merata.

\section{SIMPULAN}

Tenaga pelaksana program imunisasi sudah cukup dari jumlah dan kualifikasi pendidikannya, namun belum adanya pelatihan khusus imunisasi bagi tenaga pelaksana imunisasi. Ketersediaan sarana dan prasarana sudah mencukukupi sesuai kebutuhan, tapi pada unit praktek swasta tidak tersedia peralatan cold chain sesuai standar.

Pembuatan perencanaan program imunisasi di puskesmas dibuat berdasarkan acuan dari dinas kesehatan. Masih ada masalah petugas dalam memberikan pelayanan yang berhubungan dengan sikap dan perilaku dalam komunikasi, serta kedisiplinan petugas dalam melaksanakan SOP.

Belum tercapainya cakupan imunisasi sesuai target disebabkan oleh adanya isu-isu negatif tentang vaksin, pemahaman dan pola pikir masyarakat yang masih rendah tentang imunisasi.

\section{UCAPAN TERIMAKASIH}

Terimakasih penulis ucapkan kepada Kepala Puskesmas Lubuk Buaya.Kota Padang yang telah memberikan izin kepada penulis untuk melakukan tentang penelitian evaluasi dari pelaksanaan program imunisasi dasar.

\section{REFERENSI}

Kemenkes RI. (2015). Kesehatan Dalam Kerangka Sustainable Development Goals (SDGs). Jakarta : Kemenkes RI.

Kemenkes RI. (2015). Rencana Strategis Kementerian Kesehatan Tahun 20152019. Jakarta : Kemenkes RI.

Kemenkes RI. (2010). Gerakan Akselerasi Imunisasi Nasional Universal Child Immunization 2010-2014. Jakarta : Kemenkes RI.

Dinkes Sumbar. (2016). Laporan Akuntabilitas Kinerja Instansi Pemerintah Tahun 2015. Padang : Dinkes Sumbar.

Dinkes Padang. (2015). Profil Kesehatan Kota Padang Tahun 2014. Padang : Dinkes Padang.

IDAI. (2011). Panduan Imunisasi Anak. Jakarta : IDAI.

Azwar A. (2010). Pengantar Administrasi Kesehatan. Edisi Ketiga. Jakarta : Binarupa Aksara.

Afriyanti. (2009). Faktor - Faktor yang Berhubungan dengan Cakupan Imunisasi di Kabupaten Tegal. Semarang : Universitas Negeri Semarang. 
Sasongko. (2011). Pengaruh Diklat Terhadap Perbedaan Sikap dan Keterampilan Petugas Pengelola Vaksin Program Imunisasi pada Unit Pelayanan Kesehatan di Kabupaten Cirebon. Semarang : UNS.

Juliani A. (2012). Evaluasi Program Imunisasi Puskesmas di Kota Makasar Tahun 2012. Makasar : Unhas Makasar.

Kemenkes RI. (2013). Peraturan Menteri Kesehatan Republik Indonesia Nomor 42 Tentang Penyelenggaraan Imunisasi. Jakarta : Kemenkes RI.

Kemenkes RI. (2017). Peraturan Menteri Kesehatan Republik Indonesia Nomor 12 Tentang Penyelenggaraan Imunisasi. Jakarta : Kemenkes RI.

Zakiyah, Utami S, Sandra C. (2013). Hubungan antara Peran Petugas Kesehatan dengan Cakupan Imunisasi per Antigen Tingkat Puskesmas di kabupaten Jember. Jember : Universitas Jember.

Hutagaol. (2012). Komunikasi Petugas Kesehatan Dalam Kegiatan Posyandu di Wilayah Kerja Puskesmas Muara Siberut Kabupaten Mentawai. Jurnal Kesehatan Masyarakat Vol.6 No.2

Yulianti. (2010). Faktor - faktor yang Berhubungan dengan Kepatuhan Petugas terhadap SOP Imunisasi pada Penanganan Vaksin Campak.

Kristini T. (2008). Faktor-Faktor Resiko Kualitas Pengelolaan Vaksin Program Imunisasi yang Buruk di Unit Pelayanan Swasta (Studi Kasus di Kota Semarang. Semarang : Universitas Diponegoro.

Pracoyo, Rabea P, Puspandari N, Bagus W. (2013). Hubungan antara Pengetahuan dan Sikap Pengelola Vaksin dengan Skor Pengelolaan Vaksin di Daerah Kasus Difteri di Jawa Timur. Jakarta : Balitbang Kemenkes.

Depkes RI. (2009). Pedoman Pengelolaan
Vaksin. Jakarta : Depkes RI.

Ifadhotul A. (2009). Evaluasi Pelaksanaan Fungsi Manajemen Kegiatan Program Imunisasi Bayi dan Ibu Hamil di Puskesmas Kabupaten Bangkalan Madura Tahun 2009. Surabaya : Universitas Airlangga. 